\title{
AERIAL LASER SCANNING IN ARCHEOLOGY
}

\author{
Martina FALTYNOVA*, Karel PAVELKA* \\ *Department of Mapping and Cartography \\ Czech Technical University in Prague, Faculty of Civil Engineering \\ Thákurova 7/2077, 166 29, Prague 6, Czech Republic \\ martina.faltynova@fsv.cvut.cz \\ pavelka@fsv.cvut.cz
}

Keywords: airborne laser scanning, DTM, shaded surface

\begin{abstract}
Technology of aerial laser scanning is often well used for a DTM generation. The DTM (digital surface model) displayed in appropriate form, e.g. shaded surface, can be used as a data source for searching for archaeological sites. Aerial laser scanning data acquisition is unfortunately too expensive for non-commercial projects. It can be solution to use the ALS data acquired primarily for another reason by public service. This data has in general lower density, than expensive custom-made data, but can be borrowed for research purpose in a limited size. We tested the data from The Czech Office for Surveying, Mapping and Cadastre. The aim was to find, if it is possible to use data characterized by density of about 1 point $/ \mathrm{m}^{2}$ for archaeological research. We used the DTM in form of shaded surface and inspect the data around few well known archaeological sites from different periods. It is also possible to use different outputs from the original DTM to better display terrain discontinuities, which could be caused by human activity.
\end{abstract}

\section{INTRODUCTION}

The ALS data seems to be appropriate tool for documentation or detection archaeological sites on a larger scale, unfortunately the data is generally too expensive to be commonly used for these purposes. In our research we try to use ALS data acquired by public service, i.e. data of lower density (about 1 point $/ \mathrm{m}^{2}$ ), which is not as expensive as custommade data and can be even borrowed for free for students projects such as diploma thesis. The data was lent by The Czech Office for Surveying, Mapping and Cadastre.

\section{DATA}

The Czech Office for Surveying, Mapping and Cadastre started in 2008 with project for terrain mapping using the ALS method. The aim of mapping is to get authentic and detailed DTM of Czech Republic. Previous DTM in form of GRID $10 \times 10 \mathrm{~m}$ is based on digitizing of contours ZM 10 (Base Map 1:10 000), this contours were reached by topographic mapping and photogrammetry, its height precision is about $2-5 \mathrm{~m}$ in a forested area, which is absolutely deficient for archaeological research. About 1/3 of area is currently covered by the DTM based on ALS, until 2015 the mapping should be complete. The standard deviation in altitude of model points is up to $30 \mathrm{~cm}$. We have used the DTM displayed as shaded surface. The data was prepared in SW SCOP++, the parameters of shining are: azimuth $-315^{\circ}$, height above terrain $-45^{\circ}$, pixel size is $1 \times 1 \mathrm{~m}$. Terrain break lines are highlighted by the method of shaded surface, which is suitable for archaeological research. Remains of buildings and other terrain modification are characterized by terrain break lines, local tops or pits, which do not fit to local geomorphology.

\section{MAPPING OF THE KNOWN SITES}

We have chosen few well known archaeological sites to compare results from ALS data and results from some earlier mapping methods used by archaeologists. Archaeological research fall into noncommercial sphere, which means that simply cheap methods like stepping were used for mapping. This methods were not very precise, especially while it was realized by non-professionals. You can compare visualization of remains of stronghold Mrdice near Pardubice, the fort was first mentioned in the will of Heřman of Mrdice in the early $14^{\text {th }}$ century and had been probably left during the $15^{\text {th }}$ century. There is obvious difference between the scheme from 1989 based on stepping and situation displayed in shaded surface. 


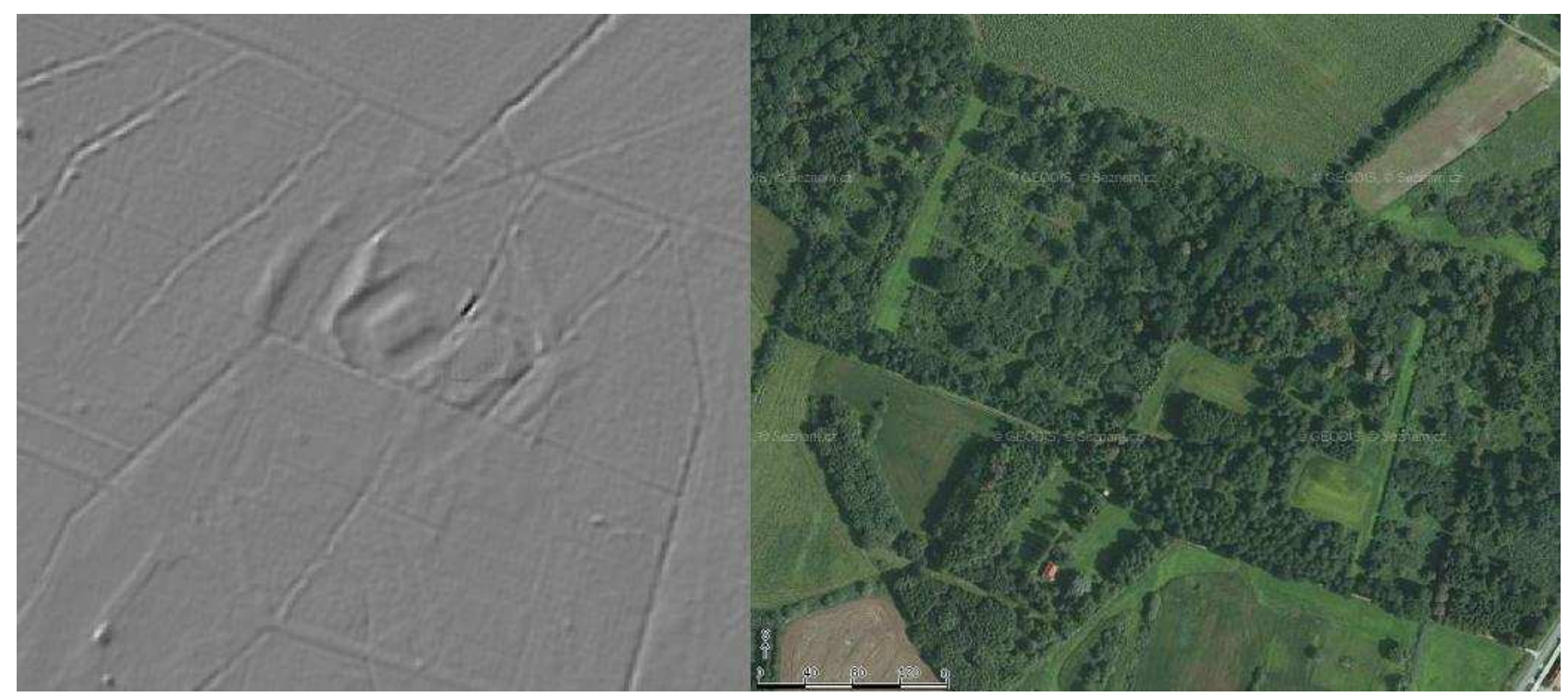

Figure 1: Mrdice - shaded surface and orthophoto

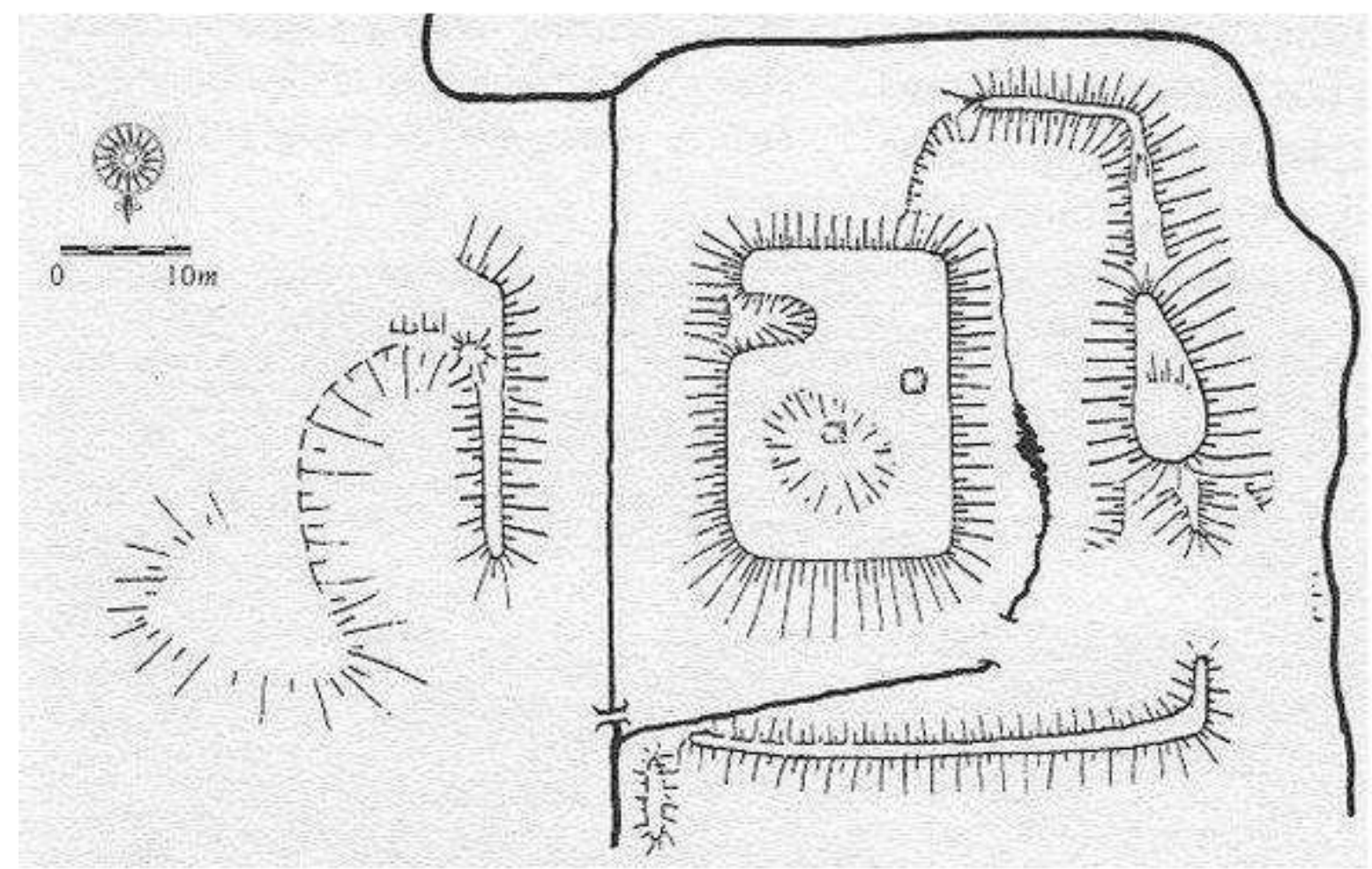

Figure 2: Mrdice - scheme [2]

Near village Provodín there is about $1.5 \mathrm{~km}$ long rampart along the hill Dlouhý vrch, which can be clearly seen in shaded surface. The rampart became from war between Prussia and Austria in the mid $18^{\text {th }}$ century. In fact the rampart was first used later, in the early $19^{\text {th }}$ century during French invasion. The rampart is up to $4 \mathrm{~m}$ height and the hill is actually covered by beech forest. 


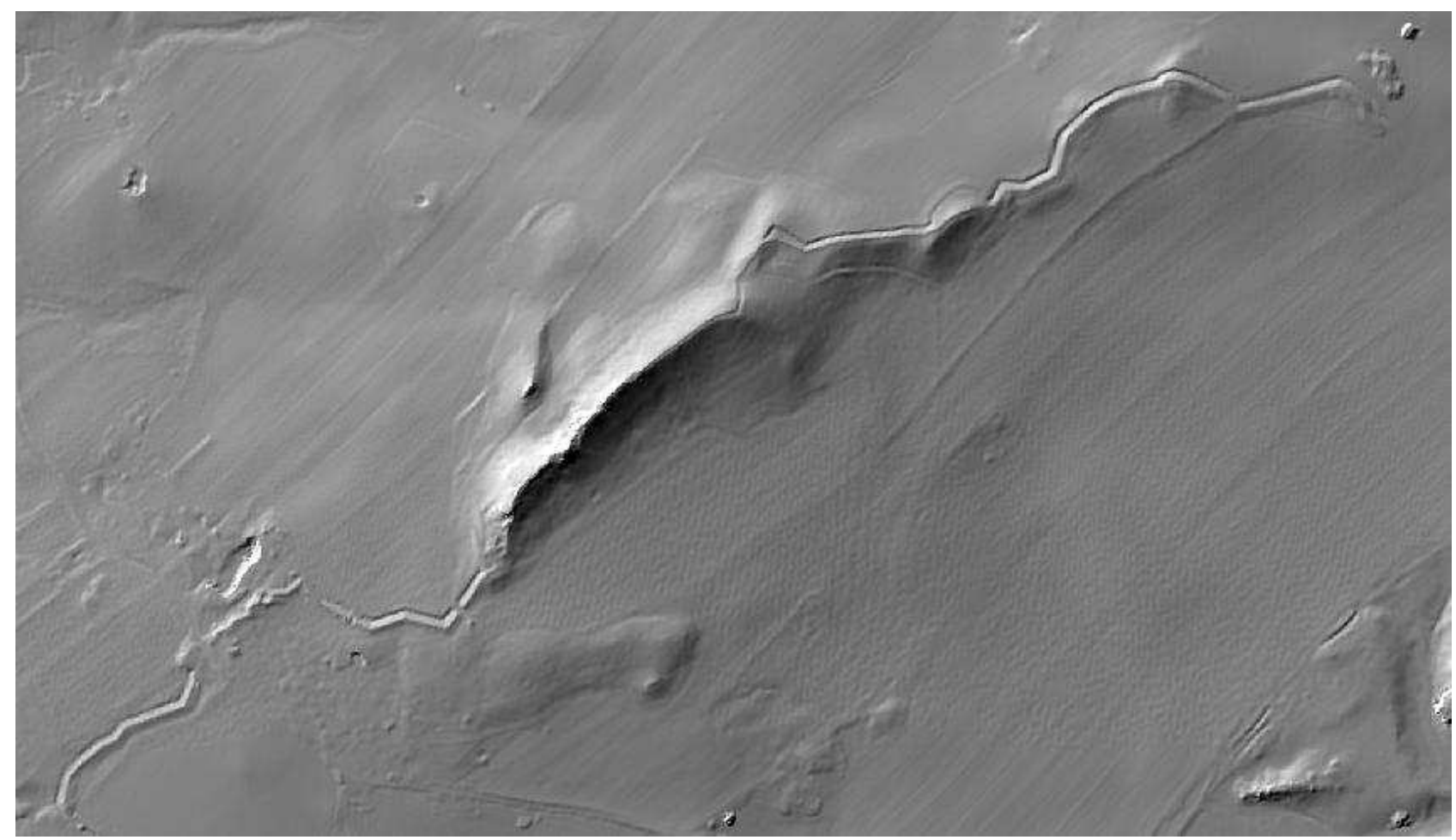

Figure 3: Provodin - shaded surface

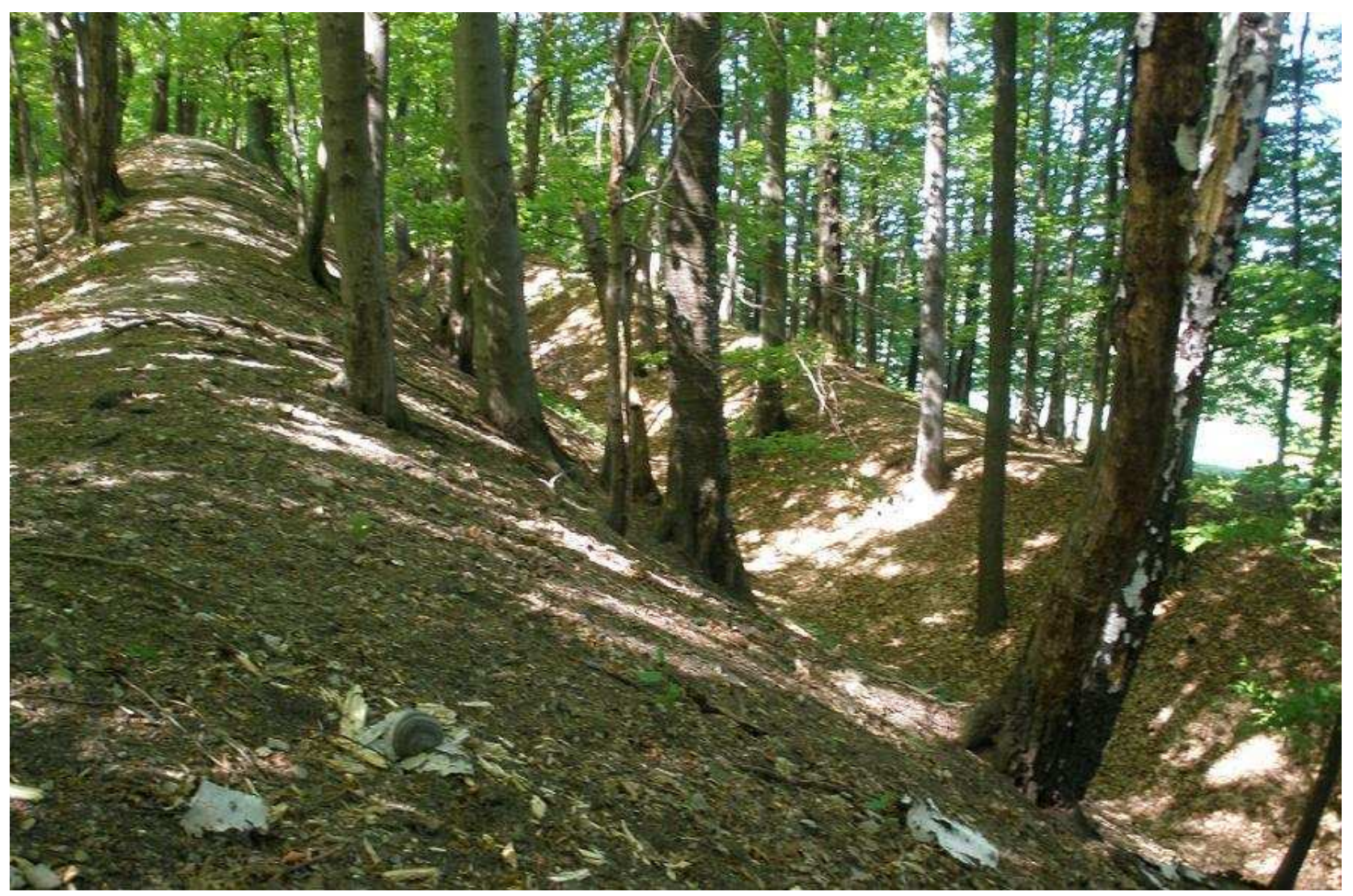

Figure 4: Provodin - rampart 


\section{SEARCHING FOR UNDOCUMENTED SITES}

The ALS data can be also used for more than mapping known sites more precisely. It can serve for searching for unknown historic sites - remains of forts, barrows, etc. Using shaded surface with resolution 1m, we are able to descry objects with size from about $10 \mathrm{~m}$. It is hard to differentiate small objects (e.g. barrows) from data noise (see Fig. 5 probably robbed barrows in forest near village Kojakovice, South Bohemia). The chance to find such an object strongly depends on season, in which the data was acquired, and the vegetation cover. It is almost impossible to perfectly classify out the returns from dense deciduous forest in summer.

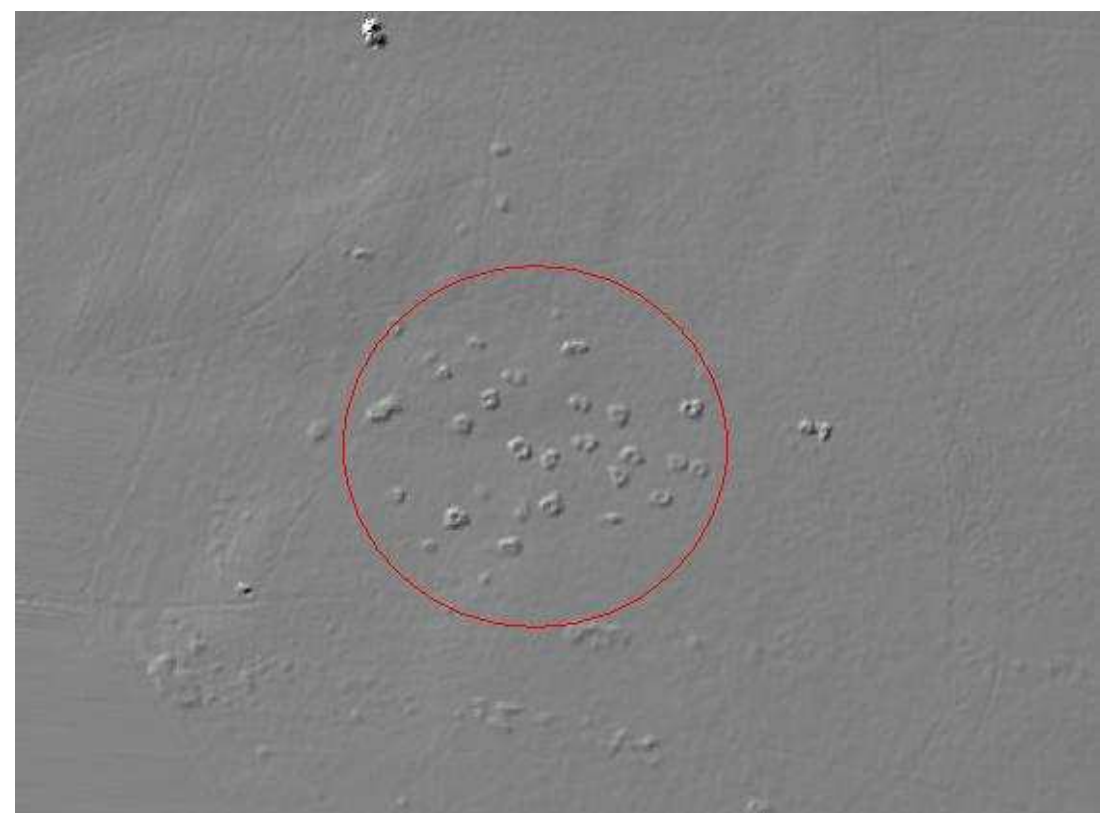

Figure 5: Kojakovice

Unfortunately, the forests are almost last places, where it is possible to find some sites, which are not destroyed by an agricultural activity. An example of this are remains of fort in Hvezdov (Ceska Lipa). There are evident remains of walls along the access way and two circumvallation with moat in between (see Fig. 8). Great part of this site is covered by young pine forest, with complicated the field survey. We have found no information about the fort, but the remains are drawn in maps of II $^{\text {nd }}$ Military Survey (1836-1852).

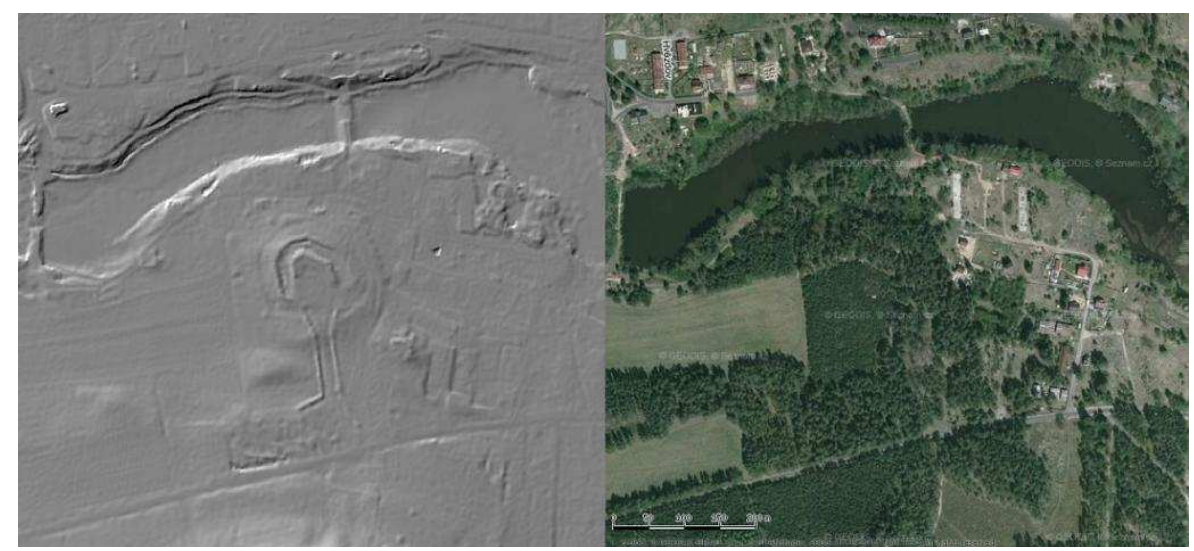

Figure 6: Hvezdov 


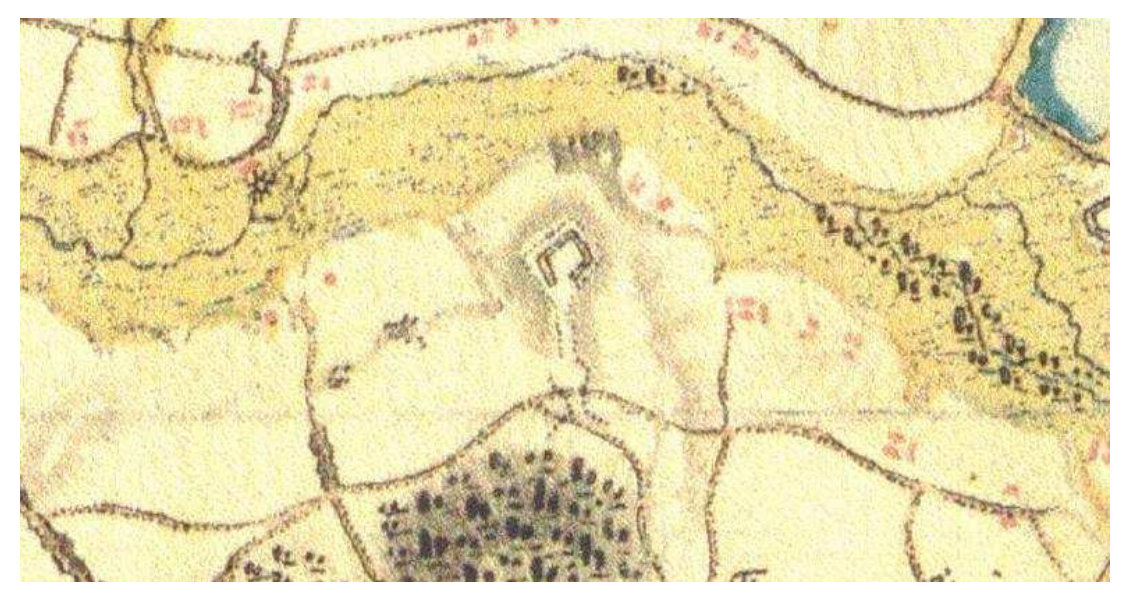

Figure 7: Hvezdov - II ${ }^{\text {nd }}$ Military Survey [5]

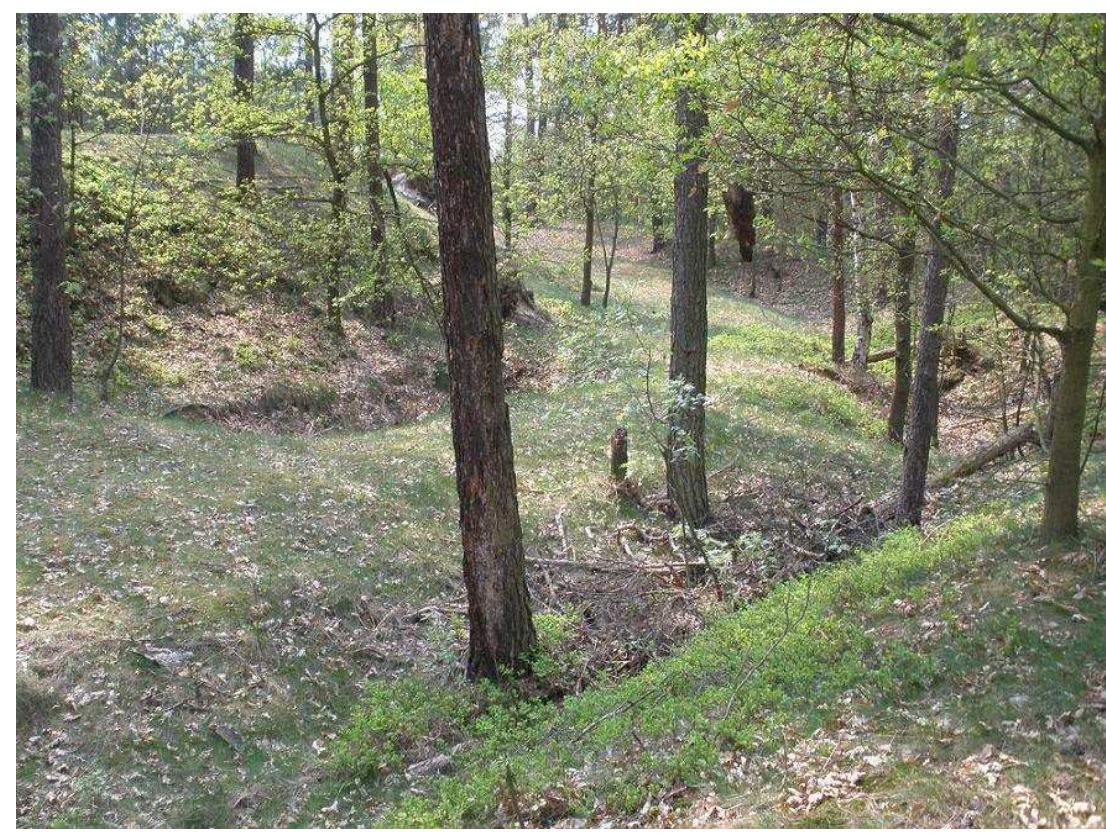

Figure 8: Hvezdov - view of the circumvallation

There are more two examples of objects that can be found in ALS data with resolution of $1 \mathrm{~m}$. The first are remains of circumvallation on the hill Certovina near Mnichovo Hradiste. And the second is a barrow in a forest above the city Mlada Boleslav.

\section{CONCLUSION}

The ALS can be excellent tool for archaeologists and other in history interested persons. In spite of the lower resolution compared to possibilities of commercial custom made data, the ALS data produced by public survey have a huge advance because of its price. After finishing of mapping by ALS project, the data will be available for whole region of Czech Republic. The resolution turns out to be sufficient for archaeological research in a large scale. There is a potential for using this data for research. 


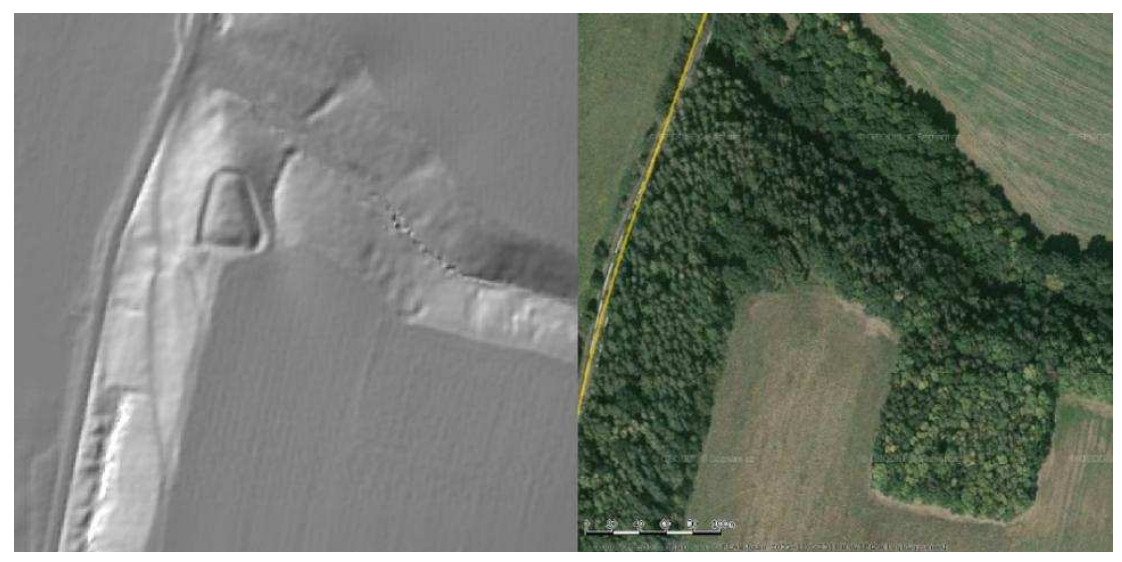

Figure 9: Mnichovo Hradiste - circumvallation

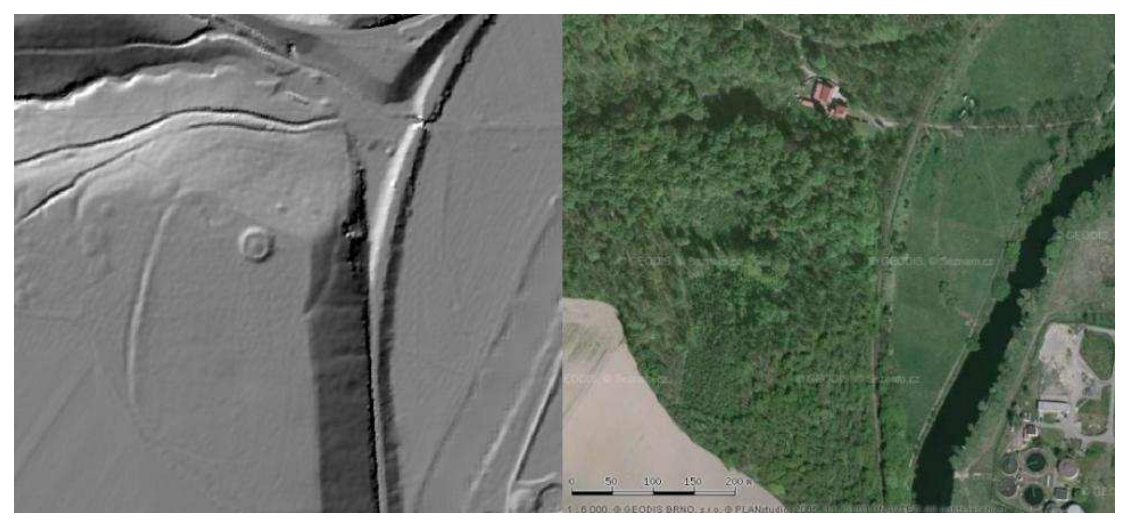

Figure 10: Mlada Boleslav - barrow

\section{REFERENCES}

[1] Hrady.cz. [online], [Retrieved 2011-04-15]. Available from Web: 〈http://www.hrady.cz>

[2] Svoboda, L. Encyklopedie ceskych tvrzi II.díl K-R. Argo 2000, p.662, ISBN-10: 80-7203-279-8.

[3] Obec Provodin. [online], [Retrieved 2011-03-28]. Available from Web: 〈http://www.obec-provodin.cz/>

[4] Sedlacek, A. Hrady, zamky a tvrze Kralovstvi Ceskeho I.-XV. Praha 1998, nakl. Argo, 2.vydani, ISBN 80-8579484-5.

[5] Presentation of old maps covering the area of Czechia, Moravia and Silesia. [online], [Retrieved 2011-05-20].

Available from Web: 〈http://oldmaps.geolab.cz>

[6] Mapy.cz [online], [Retrieved 2011-05-22]. Available from Web: http://mapy.cz

[7] Koska, B., Pospíśil, J., Štroner, M.: Innovations in the Development of Laser and Optic Rotating scanner LORS, XXIII International FIG Congress, Munich, Germany, ISBN 87-90907-52-3, 2006. Available on WWW: < http://k154.fsv.cvut.cz/ koska/publikace/publikace_en.php>

[8] Křemen, T. - Koska, B. - Pospíšil, J.: Verification of Laser Scanning Systems Quality. XXIII-rd International FIG Congress Shaping the Change [CD-ROM]. Mnichov: FIG, 2006, ISBN 87-90907-52-3

[9] Křemen, T. - Koska, B. - Pospíšil, J.: Laserscanning for Castle Documentation. Proceedings of the 23rd CIPA Symposium [CD-ROM]. Prague: ČVUT, Fakulta stavební, Katedra mapování a kartografie, 2011, p. 1-8. ISBN 978-8001-04885-6

[10] Koska, B. - Řezníček, J. : Solving Approximate Values of Outer Orientation Parameters for Projective Transformation. Proceedings of Workshop.2008. Praha: Czech Technical University in Prague, 2008, vol. A, p. 162163. ISBN 978-80-01-04016-4 